\title{
MODAL SOSIAL DALAM PEMANFAATAN BUAH TENGKAWANG DI HUTAN ADAT PIKUL
}

\author{
(Social Capital in Utilizing Tengkawang Fruits in the Pikul Costumary Forest)
}

\author{
Dewita $^{\text {1) }}$, Emi Roslinda ${ }^{2)}$, Siti Masitoh Kartikawati ${ }^{2)}$ \\ Fakultas Kehutanan Universitas Tanjungpura. Jalan Daya Nasional Pontianak 79124 \\ Email: dewitaasus2016@gmail.com.
}

\begin{abstract}
Pikul customary forest has the potential of tengkawang that was abundant and utilized by the community around the forest to fulfill their daily needs. This study aimed to determine community social capital consists of cognitive and structural social capital and the relationship of social capital how to use tengkawang fruit in the Pikul indigenous forest. This study used the concept survey methods, with data collection techniques with interviews used questionnaires and in-depth interviews with key respondents. Respondents in this study were Melayang Hamlet community who used tengkawang fruit intentionally. The magnitude level of social capital used the value interval equation and the relationship of social capital was analyzed of Sperman rating coefficient test. The results showed the cognitive social capital and the structural social capital were both classified as "high". The relationship of social capital which used of tengkawang has a direct and strong relationship, the two elements of Cognitive and structural social capital were very significant and relate with the way how to use tengkawang. The real correlation occurred in the form of a positive correlation that showed the higher level of structural social capital and cognitive social capital formed, which better used of tengkawang fruit in the Pikul customary forest.
\end{abstract}

Keywords: social capital, tengkawang fruit, Pikul costomary forest

Abstrak

Hutan Adat Pikul memiliki potensi tengkawang yang sangat melimpah. Jenis ini dimanfaatkan masyarakat sekitar hutan untuk memenuhi kebutuhan hidup. Penelitian ini bertujuan mengetahui modal sosial masyarakat yang terdiri atas modal sosial kognitif dan struktural dan hubungan modal sosial terhadap pemanfaatan buah tengkawang di hutan Adat Pikul. Penelitian ini menggunakan metode survei, melalui teknik wawancara menggunakan kuesioner dan wawancara mendalam kepada responden kunci. Responden dalam penelitian ini adalah masyarakat Dusun Melayang yang memanfaatkan buah tengkawang. Tingkat modal sosial masyarakat dianalisis menggunakan persamaan selang nilai. Sementara itu hubungan modal sosial dianalisis menggunakan uji koefisien Peringkat Sperman. Hasil penelitian menunjukan bahwa modal sosial kognitif serta modal sosial struktural tergolong "tinggi". Hubungan modal sosial terhadap pemanfaatan tengkawang memiliki hubungan yang searah dan kuat. Kedua unsur modal sosial Kognitif dan struktural berhubungan sangat nyata terhadap pemanfaatan tengkawang. Korelasi nyata yang terjadi berupa korelasi positif yang menunjukkan semakin tinggi tingkat modal sosial struktural dan modal sosial kognitif yang terbentuk, semakin baik pula pemanfaatan buah tengkawang di hutan Adat Pikul.

Kata kunci: Modal Sosial, Buah Tengkawang, Hutan Adat Pikul

\section{PENDAHULUAN}

Kawasan Hutan Adat Pikul ditetapkan sebagai Hutan Adat berdasarkan pada Surat Keputusan Menteri Lingkungan Hidup dan Kehutanan Nomor: SK.1300 / MENLHK / PSKL / PKTHA / PSL.1/3/2018 tanggal 28 Maret 2018 seluas 100 Ha. Hutan adat ini terletak di Desa Sahan Kecamatan Seluas Kabupaten Bengkayang. Hutannya didominasi oleh pohon Meranti (Shorea $s p$ ) menghasilkan buah tengkawang.

Buah tengkawang (Borneo Illipe nut) merupakan hasil hutan bukan kayu yang memiliki nilai ekonomi tinggi. Jenis ini 
sangat bermanfaat untuk meningkatkan perekonomian masyarakat terutama masyarakat di sekitar hutan. Selain kayunya, buah dan kulitnya juga dapat diolah menjadi bahan makanan maupun kerajinan tangan (Fernandes dan Maharani, 2014). Masyarakat yang tinggal di sekitar hutan Adat Pikul sangat menggantungkan hidupnya pada sumberdaya yang ada dalam hutan sebagai tempat untuk mencari nafkah. Masyarakat berkerjasama menjaga kelestarian hutan adat berdasarkan norma-norma yang diwariskan oleh nenek moyang mereka yang mampu memberikan manfaat secara lestari, produktif dan efisien sejalan dengan penelitian Suharjito dan Saputro (2017) yang menyatakan pentingnya kepercayan, aturan peran maupun jejaring sosial dalam pengelolaan sumberdaya hutan, secara nyata telah membantu masyarakat dalam pengelolaan sumber daya hutan serta modal sosial telah menjadi energi positif dalam mengelola sumber daya hutan sehingga dapat memberikan kelestarian hutan.

Kelompok masyarakat yang bekerjasama berdasarkan nilai dan normanorma dan nilai sosial yang mengakar dan disepakati dapat disebut sebagai modal sosial. Modal sosial menjadi salah satu alternatif untuk mengatasi masalah kemiskinan, kesehatan, pendidikan dan ketersediaan modal ditingkat rumah tangga dan pembangunan ekonomi, modal sosial memiliki keterkaitan positif yang nyata dengan kesejahteraan rumah tangga (pendapatan rumah tangga), semakin kuat modal sosial, semakin tinggi partisipasi dan kepadatan jaringan kerja maka semakin tinggi pula tingkat kesejahteraan rumah tangga tersebut (Miler et al, 2006) dan (Vipriyanti, 2007).
Modal sosial dalam pemanfaatan buah tengkawang di Hutan Adat Pikul menarik untuk diteliti karena hutan Adat Pikul dapat memberikan kontribusi ekonomi kepada masyarakat Dusun Melayang dengan memanfaatkan sumberdaya hutan berupa buah tengkawang. Modal sosial dengan wujud nyata seperti kepercayaan, kerjasama dan solidaritas yang terinternalisasi dalam masyarakat, serta adanya aturan, peranan dan jaringan sosial yang bekerja dalam pemanfaatan dan pengolahan tengkawang.

Masyarakat menjaga kelestarian hutan adat tersebut dengan tidak menebang pohonpohon yang berada di dalam hutan, sehingga masyarakat dapat memanfaatkan hasil hutan sebagai sumber mata pencaharian yang berkelanjutan untuk menunjang kesejahteraan perekonomiannya. Modal sosial dalam pemanfaatan buah tengkawang di hutan Adat Pikul terdiri atas unsur kognitif (kepercayaan, kerjasama, dan solidaritas) dan unsur struktural (aturan, peranan, dan jaringan) kedua unsur ini saling berkaitan dan dapat meningkatkan tindakan kolektif yang saling menguntungkan masyarakat serta dapat memberikan pengaruh untuk memperkuat modal sosial dalam pemanfaatan buah tengkawang yang berkelanjutan. Semakin kuat modal sosial maka semakin kecil kemungkinan terjadi konflik (Romzy et al, 2019) dan semakin baik pula upaya-upaya yang dilakukan masyarakat dalam kegiatan pemanfaatan dan pengelolaan tengkawang.

Penelitian ini menjelaskan bagaimana modal sosial masyarakat dalam pemanfaatan buah tengkawang dan hubungan antara modal sosial dengan pemanfaatan tengkawang di hutan Adat Pikul.

\section{METODE PENELITIAN}

Penelitian ini menggunakan konsep Uphoff (2000) yang membagi unsur-unsur 
modal sosial menjadi dua kategori yang saling berhubungan dan tidak dapat dipisahkan yaitu struktural dan kognitif. Modal sosial struktural terdiri atas peran, aturan dan jaringan dan modal sosial kognitif terdiri dari kepercayaan, kerjasama dan solidaritas. Modal sosial struktural bersifat ekstrinsik dan dapat diamati, sementara aspek kognitif tidak dapat diamati, namun keduanya saling terkait di dalam praktik, struktural datang dari hasil proses kognitif.

Penelitian ini dilaksanakan di Hutan Adat Pikul yang terletak di Dusun Melayang, Desa Sahan, Kecamatan Seluas, Kabupaten Bengkayang. Alat yang digunakan dalam penelitian ini adalah: peta lokasi, kuisioner dan kamera. Unit analisis penelitian ini adalah masyarakat Dusun Melayang, populasi dan sampel dalam penelitian ini adalah masyarakat Dusun Melayang. Jumlah populasi dalam penelitian ini adalah $282 \mathrm{KK}$. Jumlah sampel yang digunakan dalam penelitian adalah $10 \%$ dari jumlah populasi (Gay dalam Mahmud, 2011) sehingga jumlah sampel dalam penelitian ini adalah 30 orang. Penentuan sampel menggunakan teknik purposive sampling dengan kriteria: Sehat jasmani dan rohani, berprofesi sebagai petani serta masyarakat yang memanfaatkan buah tengkawang secara khusus penduduk Dusun Melayang.

Penelitian ini menggunakan metode survei, pengumpulan data dilakukan dengan wawancara menggunakan kuesioner (Nazir 2003, Singarimbun \& Effendi 2008). Data yang dikumpulkan meliputi data primer dan data sekunder. Data primer diperoleh melalui wawancara terstruktur kepada 30 responden menggunakan kuesioner dan wawancara mendalam kepada beberapa informan kunci seperti: Kepala Desa, Kepala Dusun dan ketua adat. Data Primer berupa modal sosial kognitif (kepercayaan, kerjasama dan solidaritas) modal sosial struktural (aturan, peran dan jaringan), sedangkan performansi (keadaan) pemanfaatan tengkawang terdiri dari: produktivitas, keberlanjutan dan keadilan. Data sekunder diperoleh dari datadata laporan (dokumentasi) dari instansi terkait serta hasil kajian pustaka. Analisis Tingkat modal sosial masyarakat dalam memanfaatkan buah tengkawang digunakan persamaan selang nilai (Mulyono, 2012). Jumlah kelas dalam penelitian ini adalah 3 (tiga) kelas yaitu rendah, sedang dan tinggi. Nilai untuk setiap pertanyaan bernilai 1 untuk kategori rendah, 2 untuk kategori sedang dan 3 kategori tertinggi. Analisis hubungan antara tingkat modal sosial terhadap pemanfaatan buah tengkawang dilakukan dengan uji koefiesien peringkat sperman (Rs) (Supranto, 2000). Untuk memudahkan perhitungan data diolah menggunakan SPSS versi 24.

\section{HASIL DAN PEMBAHASAN}

\section{Karakteristik Responden}

Karakteristik responden dalam penelitian ini dikelompokan menjadi 3 (tiga) yaitu umur, tingkat pendidikan dan mata pencaharian.

Selang umur responden dalam penelitian ini adalah 27-56 tahun. Umur 27-36 tahun sebanyak $20 \%$, umur 37-46 tahun sebanyak $33 \%$ dan umur 47-56 tahun sebanyak $47 \%$. Umur 47-56 tahun merupakan umur yang dominan dalam penelitian ini karena responden masih potensial dan produktif untuk melakukan kegiatan pertanian dan kegiatan lainnya untuk memenuhi kebutuhan hidupnya. 


\section{Tingkat Umur}

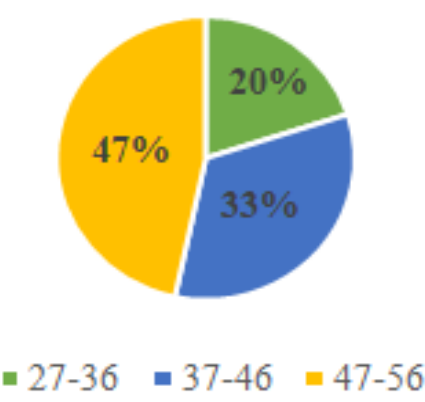

Tingkat pendidikan responden di lokasi penelitian sebanyak (40\%) responden pendidikanya sampai pada tingkat SMP. Tingkat pendidikan responden (33\%) sampai pada tingkat SD, selanjutnya untuk tingkat pendidikan hingga SLTA sebanyak (17\%) dan responden yang tidak pernah sekolah berjumlah (10\%). Hal ini menunjukkan bahwa sebagian besar responden pernah mengecam pendidikan meskipun sebagian besar hanya sampai tingkat SD.

\section{Tingkat Pendidikan}

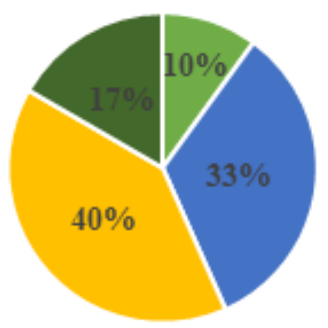

- Tidak Sekolah "SD " SMP -SMA

Mata pencaharian pokok responden adalah petani (sawah/ladang dan karet) sebagian besar pekerjaan sampingan responden adalah sebagai buruh/kuli dan tukang. Kegiatan pemanenan buah tengkawang dilakukan sekali dalam setahun yaitu dibulan Januari-Maret, kegiatan pemanenan ini dilakukan pada waktu senggang setelah menyelesaikan pekerjaan pokoknya, yang dibantu oleh anggota keluarga (isteri/suami serta anak-anak) sebagai pekerjaan sampingan.

\section{Modal sosial kognitif}

Modal sosial kognitif masyarakat dalam pemanfaatan buah tengkawang berasal dari proses mental yang menghasilkan gagasan/pemikiran yang diperkuat oleh budaya dan ideologi masyarakat yang memanfaatkan buah tengkawang. Kepercayaan, kerjasama dan solidaritas masyarakat didasari oleh norma, nilai, sikap, dan keyakinan yang diorientasikan dalam bentuk tindakan (action) sehingga menciptakan dan menguatkan tindakan kolektif masyarakat yang saling menguntungkan dalam pemanfaatan buah tengkawang.

\section{Kepercayaan (Trust)}

Kepercayaan adalah salah satu unsur yang paling penting dalam modal sosial, karena adanya kepercayaan dapat mepermudah dalam menjalin kerjasama (Fauziyah, 2017). Semakin besar rasa percaya maka akan terbangun kejasama yang kuat. Tingkat kepercayaan masyarakat dalam pemanfaatan buah tengkawang di hutan adat pikul secara ringkas disajikan pada Tabel 1. 
Tabel 1. Distribusi responden menurut tingkat kepercayaan dalam pemanfaatan buah tengkawang di hutan Adat Pikul (Table 1. Distribution of respondents according to level of confidence in the use of tengkawang fruit in the Pikul customary forest)

\begin{tabular}{|c|c|c|c|c|c|}
\hline No & $\begin{array}{l}\text { Kepercayaan responden } \\
\text { terhadap }\end{array}$ & $\begin{array}{l}\text { Skor } \\
\text { nilai }\end{array}$ & $\begin{array}{l}\text { Jumlah } \\
\text { responden }\end{array}$ & $\begin{array}{c}\text { Total nilai } \\
\text { (Skor x jlh resp) }\end{array}$ & $\begin{array}{l}\text { Persentase } \\
(\%)\end{array}$ \\
\hline \multirow[t]{4}{*}{1.} & Sesama masyarakat yang & 1 & 0 & 0 & 0 \\
\hline & memanfaatkan buah & 2 & 11 & 22 & 36,67 \\
\hline & tengkawang & 3 & 19 & 57 & 63,33 \\
\hline & & & 30 & 79 & 100,00 \\
\hline \multirow[t]{4}{*}{2.} & Masyarakat yang tidak & 1 & 0 & 0 & 0 \\
\hline & memanfaatkan tengkawang & 2 & 14 & 28 & 46,67 \\
\hline & & 3 & 16 & 48 & 53,33 \\
\hline & & & 30 & 76 & 100,00 \\
\hline \multirow[t]{4}{*}{3.} & Kemampuan masyarakat & 1 & 0 & 0 & 0 \\
\hline & dalam melestarikan pohon & 2 & 13 & 26 & 43,33 \\
\hline & tengkawang & 3 & 17 & 51 & 56,67 \\
\hline & & & 30 & 77 & 100,00 \\
\hline \multirow[t]{4}{*}{4.} & Pihak yang mendukung & 1 & 0 & 0 & 0 \\
\hline & (Kepala Desa) & 2 & 9 & 19 & 30 \\
\hline & & 3 & 21 & 63 & 70 \\
\hline & & & 30 & 81 & 100,00 \\
\hline \multirow[t]{4}{*}{5.} & Pihak yang mendukung & 1 & 0 & 0 & 0 \\
\hline & (tokoh adat) & 2 & 5 & 10 & 16,67 \\
\hline & & 3 & 25 & 75 & 83,33 \\
\hline & & & 30 & 85 & 100,00 \\
\hline \multirow[t]{5}{*}{6.} & Pihak yang mendukung & 1 & 0 & 0 & 0 \\
\hline & (LSM INTAN) & 2 & 8 & 16 & 26,67 \\
\hline & & 3 & 22 & 66 & 73,33 \\
\hline & & & 30 & 82 & 100,00 \\
\hline & Total nilai untuk tingkat ke & v & & 480 & \\
\hline
\end{tabular}

Sumber: analisis data, 2020. Jumlah responden 30 orang, jumlah kelas 3, 1(rendah), 2 (sedang), 3 (tinggi)

Tabel 1 menunjukan bahwa Masyarakat Dusun Melayang memiliki tingkat kepercayaan yang tinggi terhadap sesama masyarakat, baik yang memanfaatkan maupun tidak memanfaatakan buah tengkawang. Kepercayaan antar warga terjalin dengan baik karena mereka berasal dari suku yang sama yaitu suku Dayak Bakatik. Faktor lainnya berupa ikatan darah (seketurunan) pada sebagian besar warganya, serta adanya interaksi sosial yang selama ini terjalin antar warga.
Nilai-nilai (values) dan keyakinan (belief) yang melekat kuat menumbuhkan sikap (attitudes) dalam kehidupan seharihari warga masyarakat seperti: sikap saling percaya antar warga, hormat menghormati, sikap kekeluargaan yang tinggi, perbuatan yang dilaksanakan dengan tulus, jujur, ikhlas, empati, suka menolong, gaya hidup sederhana, serta kepedulian yang tinggi terhadap lingkungan dan alam sekitarnya. Temuan ini sejalan dengan penelitian Rinawati (2012) dan Golat et al (2020) bahwa orang-orang didalam komunitas yang memiliki latar belakang/etnis/budaya 
yang sama memiliki tingkat kepercayaan yang tinggi, karena kepercayaan dibentuk atas dasar identitas yang sama.

Tingginya kepercayaan membuat orang-orang dapat bekerjasama dengan lebih efektif. Kemakmuran dapat dicapai pada masyarakat yang tinggi tingkat kepercayaannya dibandingkan dengan masyarakat yang rendah tingkat kepercayaannya (Fukuyama 2007). Hubungan baik antar anggota kelompok dalam suatu ikatan organisasi sosial kemasyarakatan seperti lembaga adat membentuk suatu kepercayaan bahwa ikatan tersebut dapat terjalin secara berkesinambungan dalam jangka panjang sehingga ada keterikatan yang saling menguntungkan (Yuliarmi, 2013).

Warga yang tidak memanfaatkan buah tengkawang secara bersama menjaga kelestarian pohon tengkawang dengan tidak menebang pohon tengkawang maupun pohon lain yang ada di hutan Adat Pikul, sehingga dapat merasakan manfaat yang jasa lingkungan dari hutan Adat Pikul. Terjaganya kelestarian hutan adat dapat mempertahankan siklus hidrologi, seperti pasokan air bersih yang melimpah dimanfaatkan sebagian besar masyarakat Desa Sahan.

Tingkat kepercayaan masyarakat terhadap tokoh adat dan Lembaga Swadaya Masyarakat (LSM) Institut Riset dan Pengembangan Teknologi Hasil Hutan (INTAN) tergolong tinggi. Tokoh adat melakukan berbagai upaya untuk tetap menjaga kelestarian dan keberlanjutan dalam pemanfaatan buah tengkawang salah satunya dengan membentuk "kelompok tani tengkawang layar", kelompok ini berfungsi sebagai tempat pengolahan buah tengkawang menjadi mentega hijau sekaligus pemasarannya. Tokoh adat dan LSM sangat berperan mendampingi kelompok tani dalam pengelolaan dan pemanfaatan buah tengkawang. LSM INTAN juga membantu mencari donatur dan konsumen untuk memasarkan mentega hijau yang dihasilkan oleh kelompok tani dan memberi pelatihan kepada kelompok tani untuk mengolah buah tengkawang menjadi es cream dan kue. Temuan ini sejalan dengan hasil penelitian Sunkar, et,al. (2013) yang dilakukan di Taman Nasional Kutai (TNK) dimana masyarakat percaya terhadap LSM karena program-program yang dibuat dalam kegiatan pendampingan pengembangan Ekowisata Kabo Jaya oleh CIFOR, PILI, dan BIKAL berjalan dengan baik.

Kepercayaan antar sesama warga tergolong tinggi, dilandasi oleh normanorma, nilai-nilai, sikap dan keyakinan yang berasal dari nilai-nilai ajaran yang mereka anut serta melekat kuat dan sudah berlaku secara turun temurun dalam masyarakat sebagai norma-norma yang diakui, dipatuhi, dan dijadikan pedoman. Tanpa adanya rasa percaya antara anggota kelompok dan pengurus masalah yang terjadi tidak akan terselesaikan (Zulfanarisyandra, 2009). Kepercayaan merupakan modal sosial yang penting untuk membangun komunitas, baik untuk komunitas itu sendiri maupun hubungannya dengan komunitas yang lainnya. Temuan ini sejalan dengan Suharjito dan Saputro (2008) bahwa tingkat kepercayaan warga masyarakat yang kuat di landasi oleh norma, nilai, sikap dan keyakinan yang membuat hubungan sosial dan kerjasama mereka efektif sehingga mampu mendukung 
terpeliharanya upaya-upaya untuk terus menjaga kelestarian hutan.

\section{Kerjasama (cooperation)}

Bentuk kerjasama masyarakat dalam mengelola hutan adat pikul dilandasi oleh nilai-nilai, sikap dan keyakinan yang bersumber dari ajaran yang mereka anut secata turun temurun serta adanya hubungan kekeluargaan pada sebagian warga sehingga semakin memperkuat ikatan kekeluargaan (Mulyono, 2012). Tingkat kerjasama masyarakat dalam pemanfaatan buah tengkawang di hutan adat pikul secara ringkas disajikan pada Tabel 2.

Tabel 2. Distribusi responden menurut tingkat kerjasama dalam pemanfaatan buah tengkawang di hutan Adat Pikul (Table 2. Distribution of respondents according to level of cooperation in the use of tengkawang fruit in the Pikul customary forest)

\begin{tabular}{|c|c|c|c|c|c|}
\hline No & Kerjasama responden untuk & $\begin{array}{l}\text { Skor } \\
\text { nilai }\end{array}$ & $\begin{array}{c}\text { Jumlah } \\
\text { responden }\end{array}$ & $\begin{array}{c}\text { Total nilai } \\
\text { (Skor } \mathrm{x} \text { jlh resp) }\end{array}$ & $\begin{array}{c}\text { Persentase } \\
(\%)\end{array}$ \\
\hline \multirow[t]{4}{*}{1.} & Untuk melakukan & 1 & 0 & 0 & 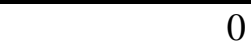 \\
\hline & lingkungan & 2 & 7 & 14 & 23,33 \\
\hline & & 3 & 23 & 69 & 76,67 \\
\hline & & & 30 & 83 & 100 \\
\hline \multirow[t]{5}{*}{2.} & tengkawang & 1 & 0 & 0 & 0 \\
\hline & bersama-sama & 2 & 3 & 6 & 10 \\
\hline & & 3 & 27 & 81 & 90 \\
\hline & & & 30 & 87 & 100 \\
\hline & Total nilai untuk tingkat kerjasa & & & 170 & \\
\hline
\end{tabular}

Sumber: analisis data, 2020. Jumlah responden 30 orang, jumlah kelas 3, 1(rendah), 2 (sedang), 3 (tinggi)

Tingkat kerjasama masyarakat Dusun Melayang dalam melakukan kegiatan pemanenan buah tengkawang termasuk dalam kategori tinggi. Masyarakat melakukan kegiatan pemanenan buah tengkawang secara bersama-sama, serta memiliki hak dan kewajiban yang sama. Semua masyarakat berhak memanen buah tengkawang yang berjatuhan pada saat musim panen tiba sesuai dengan aturanaturan yang berlaku dan telah disepakati bersama. Masyarakat yang memanfaatkan dan tidak memanfaatkan buah tengkawang di hutan adat pikul mempunyai kewajiban untuk memelihara kelestarian hutan adat pikul sehingga semua warga dapat merasakan dampak yang diberikan oleh hutan Adat Pikul.

Tradisi kerjasama dan gotong-royong baik dalam kegiatan lingkungan/ kemasyarakatan sehari-hari maupun dalam kegiatan pemanfaatan buah tengkawang dilandasi oleh nilai-nilai sikap dan keyakinan yang bersumber dari nilai-nilai yang melekat kuat dan sudah berlaku secara turun temurun. Kemampuan kerjasama antar warga komunitas dalam pengelolaan hutan adat yang tinggi, dilandasi oleh nilai-nilai, sikap, dan keyakinan yang melekat pada masingmasing individu. Hal ini menguatkan hubungan sosial. Kepercayaan dan pembalasan (reciprocation) merupakan cara untuk membangun hubungan dengan orang lain (Uphoff, 2000). Kepercayaan dilandasi oleh norma, nilai, sikap, dan keyakinan sehingga kerjasama menjadi efektif.

Temuan ini sejalan dengan hasil penelitian Uphoff (2000) bahwa unsur 
modal sosial berupa kerjasama dapat menghasilkan keuntungan material secara substantif. Organisasi petani yang dibentuk ternyata dapat menghasilkan panen padi diluar perkiraan pada saat terjadi kelangkaan air (1997). Kerjasama yang efektif, khususnya dalam hal berbagi air yang langka, petani justru mendapatkan hasil yang lebih baik daripada panen normal/biasanya. Keberhasilan itu terjadi karena telah menghidupkan kerjasama dan hubungan sosial baru dengan mengaktifkan norma-norma, nilai-nilai, sikap dan keyakinan tertentu sebagai bentuk modal sosial kognitif.

\section{Solidaritas (solidarity)}

Tingkat solidaritas masyarakat dalam pemanfaatan buah tengkawang di hutan adat pikul secara ringkas disajikan pada Tabel 3.

Tabel 3. Distribusi responden menurut tingkat Solidaritas dalam pemanfaatan buah tengkawang di hutan Adat Pikul. (Table 3. Distribution of respondents according to level of solidarity in the use of tengkawang fruit in the Pikul customary forest)

\begin{tabular}{|c|c|c|c|c|c|}
\hline No & Bentuk solidaritas & $\begin{array}{l}\text { Skor } \\
\text { nilai }\end{array}$ & $\begin{array}{c}\text { Jumlah } \\
\text { responden }\end{array}$ & $\begin{array}{c}\text { Total nilai } \\
\text { (Skor } \mathrm{x} \text { jlh resp) }\end{array}$ & $\begin{array}{c}\text { Persentase } \\
(\%)\end{array}$ \\
\hline \multirow[t]{4}{*}{1.} & Menjaga kelestarian & 1 & 0 & 0 & 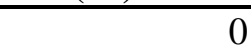 \\
\hline & tengkawang & 2 & 12 & 24 & 40,00 \\
\hline & & 3 & 18 & 54 & 60,00 \\
\hline & & & 30 & 78 & 100,00 \\
\hline \multirow[t]{4}{*}{2.} & Meminta bantuan & 1 & 21 & 21 & 70,00 \\
\hline & memungut tengkawang & 2 & 9 & 18 & 30,00 \\
\hline & & 3 & 0 & 0 & 0 \\
\hline & & & 30 & 39 & 100,00 \\
\hline \multirow[t]{4}{*}{3.} & Berbagi pengetahuan & 1 & 0 & 0 & 0 \\
\hline & & 2 & 7 & 14 & 23,33 \\
\hline & & 3 & 23 & 69 & 76,67 \\
\hline & & & 30 & 83 & 100,00 \\
\hline \multirow[t]{4}{*}{4.} & Memperkaya pengetahuan & 1 & 0 & 0 & 0 \\
\hline & & 2 & 6 & 12 & 20,00 \\
\hline & & 3 & 24 & 72 & 80,00 \\
\hline & & & 30 & 84 & 100,00 \\
\hline \multirow[t]{4}{*}{5.} & Mengajak warga & 1 & 0 & 0 & 0 \\
\hline & buah tengkawang & 2 & 9 & 18 & 30,00 \\
\hline & & 3 & 21 & 63 & 70,00 \\
\hline & & & 30 & 81 & 100,00 \\
\hline \multicolumn{3}{|c|}{ Total nilai untuk tingkat solidaritas } & & 365 & \\
\hline
\end{tabular}

Tingkat solidaritas masyarakat di Dusun Melayang tergolong tinggi. Masyarakat bersama-sama menjaga kelestarian pohon tengkawang, baik yang memanfaatkan maupun yang tidak memanfaatkan buah tengkawang, bersama-sama menjaga kelestarian pohon tengkawang. Warga memanen/mengambil buah tengkawang untuk dijual ketempat penampungan buah tengkawang yang ada di Dusun Melayang yaitu kelompok tani "Tengkawang Layar". Solidaritas antar warga dapat dilihat dengan rasa memiliki antar anggota sehingga kerukunan dan persatuan warga meningkat yaitu cara silahturahmi, bertukar pengalaman dan kekompakan (Cahyono, 2012).

Solidaritas yang tinggi menekankan pada kebersamaan yang muncul akibat adanya interaksi antar individu sehingga 
individu-individu melakukan sebuah kerjasama (Coleman, 1988). Tingkat solidaritas antar sesama warga di Dusun Melayang tergolong tinggi, karena dilandasi oleh norma-norma, nilai-nilai, sikap dan keyakinan yang melekat kuat pada setiap individu dan sudah berlaku secara turun temurun serta terinternalisasi dalam masyarakat. Nilai-nilai yang melekat pada warga mendukung terciptanya tingkat solidaritas yang tinggi antar sesama warga tersebut bersumber dari ajaran dianut (agama) oleh masyarakat Dusun Melayang.

Rudito dan Famiola (2008) menjelaskan bahwa solidaritas yang umum terjadi di pedesaan adalah solidaritas mekanik yang mengikat individu karena kebersamaan bukan berdasar status sosial, sehingga status sosial yang rendah tidak menghalangi orang untuk peduli terhadap sesama dan lingkungannya. Jika dikaitkan dengan teori Durkheim (1982) yang dijelaskan oleh Jones (2009), maka bentuk solidaritas yang terjadi pada warga masyarakat Dusun Melayang adalah termasuk solidaritas mekanik.

Dikategorikan solidaritas mekanik karena warga Dusun Melayang yang memanfaatkan buah tengkawang tersebut termasuk kelompok masyarakat tradisional (pra-modern), dimana mereka hidup dengan cara yang hampir sama antara yang satu dengan yang lain, solidaritas dicapai secara otomatis. Temuan ini sejalan dengan hasil penelitian Uphoff (2000) bahwa solidaritas yang dibangun dengan membangkitkan kembali nilai-nilai keadilan dan altruisme yang ada dalam pikiran kognitif petani melalui sebuah tradisi .

\section{Modal Sosial Struktural}

Modal sosial struktural dalam pemanfaatan buah tengkawang berkaitan dengan beragam bentuk organisasi sosial, khususnya aturan, peranan serta jaringan yang mendukung empat fungsi dasar dan kegiatan yang diperlukan untuk tindakan kolektif, yaitu pembuatan keputusan, mobilisasi dalam pengelolaan sumberdaya, komunikasi dan koordinasi, dan resolusi konflik. Dalam pemanfaatan buah tengkawang, aturan, peranan, serta jaringan mampu memfasilitasi terciptanya tindakan kolektif yang saling menguntungkan khususnya dalam melahirkan pola-pola interaksi yang membuat hasil produktif, efisien, adil dan berkelanjutan.

\section{Aturan (role)}

Tingkat aturan masyarakat dalam pemanfaatan buah tengkawang di hutan adat pikul secara ringkas disajikan pada Tabel 4. 
Tabel 4. Distribusi responden menurut tingkat Solidaritas dalam pemanfaatan buah tengkawang di hutan Adat Pikul. (Table 4. Distribution of respondents according to level of solidarity in the use of tengkawang fruit in the Pikul customary forest)

\begin{tabular}{|c|c|c|c|c|c|}
\hline No & Bentuk solidaritas & $\begin{array}{l}\text { Skor } \\
\text { nilai }\end{array}$ & $\begin{array}{l}\text { Jumlah } \\
\text { responden }\end{array}$ & $\begin{array}{c}\text { Total nilai } \\
\text { (Skor } x \text { jlh resp) }\end{array}$ & $\begin{array}{c}\text { Persentase } \\
(\%)\end{array}$ \\
\hline \multirow[t]{4}{*}{1.} & Menjaga kelestarian pohon & 1 & 0 & 0 & 0 \\
\hline & tengkawang*) & 2 & 12 & 24 & 40,00 \\
\hline & & 3 & 18 & 54 & 60,00 \\
\hline & & & 30 & 78 & 100,00 \\
\hline \multirow[t]{4}{*}{2.} & Meminta bantuan untuk & 1 & 21 & 21 & 70,00 \\
\hline & memungut tengkawang*) & 2 & 9 & 18 & 30,00 \\
\hline & & 3 & 0 & 0 & 0 \\
\hline & & & 30 & 39 & 100,00 \\
\hline \multirow[t]{4}{*}{3.} & Berbagi pengetahuan**) & 1 & 0 & 0 & 0 \\
\hline & & 2 & 7 & 14 & 23,33 \\
\hline & & 3 & 23 & 69 & 76,67 \\
\hline & & & 30 & 83 & 100,00 \\
\hline \multirow[t]{4}{*}{4.} & Memperkaya pengetahuan**) & 1 & 0 & 0 & 0 \\
\hline & & 2 & 6 & 12 & 20,00 \\
\hline & & 3 & 24 & 72 & 80,00 \\
\hline & & & 30 & 84 & 100,00 \\
\hline \multirow[t]{5}{*}{5.} & Mengajak warga memanaen & 1 & 0 & 0 & 0 \\
\hline & buah tengkawang**) & 2 & 9 & 18 & 30,00 \\
\hline & & 3 & 21 & 63 & 70,00 \\
\hline & & & 30 & 81 & 100 \\
\hline & Total nilai untuk tingkat solidar & & & 365 & \\
\hline
\end{tabular}

Sumber: Analisis data, 2020 Jumlah responden 30 orang

Keterangan (*) kriteria skor nilai: 1(tidak paham), 2 (cukup paham) dan 3 (paham)

(**) kriteria skor nilai: 1(rendah), 2 (sedang) dan 3 (tinggi)

Tingkat aturan dalam pemanfaatan buah tengkawang di hutan adat pikul tergolong sedang. Warga tidak paham terhadap aturan-aturan tertulis (aturan formal) yang mengatur masyarakat dalam kegiatan pengelolaan dan pemanfaatan buah tengkawang yang ada di dalam hutan Adat Pikul, hal ini sebabkan belum ada aturan yang tertulis mengatur tentang pemanfaatan buah tengkawang. Bahkan Peraturan Daerah (baik Provinsi maupun Kabupaten) tentang Hutan adat, karena aturan-aturan tersebut belum terinternalisasi sebagai nilai-nilai yang diakui, dipatuhi, dan dijadikan pedoman bertindak warganya, dan belum terbukti secara langsung dapat berfungsi dan bermanfaat untuk mengelola dan melestarikan pohon tengkawang dengan baik.

Sementara itu tingkat pemahaman masyarakat terhadap aturan tidak tertulis tergolong tinggi, masyarakat paham terhadap aturan yang tidak tertulis yang mereka jalani sehari-hari, warga sangat berpegang teguh pada aturan-aturan yang berlaku meskipun hanya bersifat aturan lisan yang diwariskan dari leluhur mereka. temuan ini sejalan dengan penelitian yang dilakukan oleh Anen (2012) bahwa aturan tidak tertulis yang berlaku berupa cara (usage), kebiasaan (folkways), dan tata kelakuan (mores) yang merupakan budaya yang sudah berlaku secara turun temurun 
dan terinternalisasi dalam masyarakat. Di hutan adat ini belum ada ditemukan pelanggaran yang terjadi. Warga bersamasama memungut buah tengkawang yang jatuh dari pohonnya pada musim penen tiba. Masyarakat bebas mengambil hasil dari buah tengkawang tersebut tentunya harus mengikuti aturan-aturan adat yang ada seperti tidak boleh memanjat pohon tengkawang untuk mengambil buahnya karena buah yang di ambil hanya buah yang jatuh dari atas pohon. Aturan-aturan adat (norma-norma) tersebut meskipun tidak tertulis tetapi telah berlaku secara turun temurun dan terinternalisasi dalam masyarakat sebagai norma-norma yang diakui, dipatuhi, dan dijadikan pedoman bertindak serta masyarakat bersedia untuk saling menguatkan hubungan sosial, ini karena aturan yang berlaku lebih bersifat turun temurun dan terinternalisasi dalam masyarakat (Roslinda et al. 2017).

Hasil penelitian ini sejalan dengan pendapat Uphoff (1986) yang mendefinisikan kelembagaan lokal sebagai norma-norma dan tingkah laku yang biasa berlaku dalam suatu periode tertentu untuk melayani tujuan kolektif yang akan menjadi nilai bersama. Aturan-aturan tidak tertulis berupa norma-norma yang berlaku pada masyarakat yang memanfaatkan buah tengkawang tersebut memiliki kekuatan mengikat yang berbeda-beda sesuai dengan tingkatannya. Mengacu pada Soekanto (2009) maka norma-norma yang berlaku pada masyarakat Dusun Melayang yang memanfaatkan buah tengkawang tersebut, terbagi menjadi tiga tingkatan, yaitu pertama, cara; dimana sanksi dari masyarakat atas pelanggarannya hanya dianggap janggal, seperti tidak diperbolehkan/ larangan memanen buah tengkawang dengan cara memanjat/menjolok apalagi menebang pohon yang sedang berbuah. Kedua, kebiasaan; dimana sanksi dari masyarakat atas pelanggarannya adalah berupa celaan, seperti membuang sampah di dalam hutan adat. Ketiga, tata kelakuan; yang mana sanksi dari masyarakat atas pelanggarannya adalah dihukum, seperti menebang pohon yang ada di dalam hutan adat.

Semakin baik tingkat pemahaman dan ketaatan masyarakat terhadap aturan, berarti aturan tersebut telah berfungsi dalam pengambilan keputusan, mobilisasi sumber daya, komunikasi dan koordinasi, serta resolusi konflik dalam pemanfaatan buah tengkawang tersebut secara baik dan efektif, sehingga tindakan kolektif diantara warga menjadi mudah dilakukan dalam menjaga dan memelihara kelestarian pohon tengkawang dengan baik. Hal ini sejalan dengan Suharjito dan Saputro (2008) bahwa pada masyarakat terdapat nilai-nilai, norma-norma, dan tata kelakuan yang menjadi pedoman bertindak warganya dalam kegiatan pengelolaan sumberdaya hutan dan lahan yang berlaku hingga sekarang.

\section{Peranan (roles)}

Tingkat peran masyarakat dalam pemanfaatan buah tengkawang di hutan adat pikul secara ringkas disajikan pada Tabel 5 
Tabel 5. Distribusi responden menurut tingkat peranan para tokoh dalam pemanfaatan buah tengkawang di hutan Adat Pikul. (Table 5. Distribution of respondents according to the level of the role of the figures in the utilization of tengkawang fruit in the Pikul customary forest)

\begin{tabular}{|c|c|c|c|c|c|}
\hline No & Peran & $\begin{array}{l}\text { Skor } \\
\text { nilai }\end{array}$ & $\begin{array}{c}\text { Jumlah } \\
\text { responden }\end{array}$ & $\begin{array}{c}\text { Total nilai } \\
\text { (Skor } \mathrm{x} \text { jlh resp) } \\
\end{array}$ & $\begin{array}{c}\text { Persentase } \\
(\%)\end{array}$ \\
\hline \multirow[t]{4}{*}{1.} & Tokoh Adat & 1 & 0 & 0 & 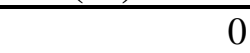 \\
\hline & & 2 & 6 & 12 & 20,00 \\
\hline & & 3 & 24 & 72 & 80,00 \\
\hline & & & 30 & 84 & 100,00 \\
\hline \multirow[t]{4}{*}{2.} & Kepala Desa & 1 & 0 & 0 & 0 \\
\hline & & 2 & 16 & 32 & 53,33 \\
\hline & & 3 & 14 & 42 & 46,67 \\
\hline & & & 30 & 74 & 100,00 \\
\hline \multirow[t]{4}{*}{3.} & Pemerintah Daerah & 1 & 18 & 18 & 60,00 \\
\hline & & 2 & 12 & 24 & 40,00 \\
\hline & & 3 & 0 & 0 & 0 \\
\hline & & & 30 & 42 & 100,00 \\
\hline \multirow[t]{4}{*}{4.} & LSM & 1 & 0 & 0 & 0 \\
\hline & & 2 & 8 & 16 & 26,67 \\
\hline & & 3 & 22 & 66 & 73,33 \\
\hline & & & 30 & 82 & 100,00 \\
\hline \multicolumn{3}{|c|}{ Total nilai untuk tingkat peran } & & 282 & \\
\hline
\end{tabular}

Membangun modal sosial struktural di dalam sebuah komunitas selain membutuhkan aturan juga sangat membutuhkan peran-peran baik formal maupun informal. Tingkat peranan tokoh adat tergolong tinggi dalam pengelolaan dan pemanfaatan buah tengkawang di hutan Adat Pikul.

Untuk memudahkan masyarakat dalam pemasaran buah tengkawang, tokoh adat bersama dengan Kepala Desa membentuk "kelompok tani tengkawang layar" kelompok tani inilah yang membeli buah tengkawang dari masyarakat yang kemudian diolah menjadi mentega hijau. Tidak hanya itu, peran tokoh adat juga sebagai pembuat kebijakan/peraturan yang ada dalam hutan adat tersebut yang harus diikuti oleh semua warga.

Uphoff (2000), menjelaskan bahwa peranan (roles) dan aturan (rules) mendukung empat fungsi dasar dan kegiatan yang diperlukan untuk tindakan kolektif, yaitu pembuatan keputusan, mobilisasi dan pengelolaan sumberdaya, komunikasi dan koordinasi, dan resolusi konflik.

Peran LSM, sangat membantu tokoh adat dalam mengelola dan memanfaatkan hasil hutan bukan kayu dari hutan adat berupa buah tengkawang. Selain mendampingi masyarakat, LSM juga berperan dalam memberikan bantun berupa mesin pengolahan buah tengkawang, yang diperoleh dari pengalangan dana para investor. Mesin tersebut diberikan kepada "kelompok tani tengkawang layar" yang digunakan untuk mengolah buah tengkawang menjadi mentega hijau. Dengan adanya mesin ini masyarakat tidak perlu keluar dari Dusun untuk menjual hasil panaennya. Selain jarak yang cukup dekat harga beli juga tinggi, dengan demikian dapat menghemat 
biaya angkutan. Selain itu masyarakat juga tidak perlu menjemur buah tengkawang yang dipungut di dalam hutan adat. Setelah memungut dapat langsung dijual ke "kelompok tani tengkawang layar", sehingga sangat membantu meringankan pekerjaan masyarakat. Temuan ini sejalan dengan penelitanan (Cahyono, 2012), bahwa untuk meningkatkan optomalisasi modal sosial dapat dilakukan dengan cara menberikn bimbingan dan pembinaan kepada masyarakat sesuai kebutuhannya dan pembinaan dalam pemasaran hasil produksi serta pelatihan akses modal bagi para petani.

\section{Jaringan (network)}

Tingkat Jaringan masyarakat dalam pemanfaatan buah tengkawang di hutan adat Pikul secara ringkas disajikan pada Tabel 6.

Tabel 6. Distribusi responden menurut tingkat Jaringan dalam pemanfaatan buah tengkawang di hutan Adat Pikul. (Table 6. Distribution of respondents according to network level in utilizing tengkawang fruit in Pikul customary forest)

\begin{tabular}{|c|c|c|c|c|c|}
\hline No & Hubungan jaringan & $\begin{array}{l}\text { Skor } \\
\text { nilai }\end{array}$ & $\begin{array}{l}\text { Jumlah } \\
\text { responden }\end{array}$ & $\begin{array}{c}\text { Total nilai } \\
\text { (Skor } x \text { jlh resp) }\end{array}$ & $\begin{array}{c}\text { Persentase } \\
(\%)\end{array}$ \\
\hline \multirow[t]{4}{*}{1.} & masyarakat terhadap lembaga & 1 & 20 & 20 & 66,67 \\
\hline & formal & 2 & 10 & 20 & 33,33 \\
\hline & & 3 & 0 & 0 & 0 \\
\hline & & & 30 & 40 & 100,00 \\
\hline \multirow[t]{4}{*}{2.} & masyarakat terhadap lembaga & 1 & 0 & 0 & 0 \\
\hline & non formal & 2 & 2 & 4 & 6,67 \\
\hline & & 3 & 28 & 84 & 93,33 \\
\hline & & & 30 & 88 & 100,00 \\
\hline \multirow[t]{4}{*}{3.} & masyarakat & 1 & 0 & 0 & 0 \\
\hline & mengikuti organisasi & 2 & 19 & 38 & 63,33 \\
\hline & & 3 & 11 & 33 & 36,67 \\
\hline & & & 30 & 71 & 100,00 \\
\hline \multirow[t]{4}{*}{4.} & Kerjasama dalam organisasi & 1 & 0 & 0 & 0 \\
\hline & & 2 & 17 & 34 & 56,67 \\
\hline & & 3 & 13 & 39 & 43,33 \\
\hline & & & 30 & 73 & 100,00 \\
\hline \multicolumn{3}{|c|}{ Total nilai untuk tingkat jaringan } & & 272 & \\
\hline
\end{tabular}

Tingkat jaringan tergolong rendah, karena belum ada organisasi/lembaga formal yang bergerak dalam bidang pemanfaatan buah tengkawang, bahkan hingga saat ini juga tidak ada rencana atau keinginan mereka untuk membentuk organisasi/lembaga formal. Mereka merasa belum perlu membentuk organisasi/ lembaga formal dalam pengelolaan dan pemanfaatan buah tengkawang, karena pemanfaatan buah tengkawang hanyalah pekerjaan sampingan. Selain itu, mereka juga beralasan bahwa sekalipun tanpa ada ikatan organisasi/lembaga formal, mereka tidak pernah terkendala, karena mereka telah memiliki ikatan kekeluargaan yang tinggi dimana mereka selalu saling mendukung dan bekerjasama dengan baik dalam kegiatan pemanfaatan buah tengkawang. Hal ini menunjukan bahwa sifat jaringan yang terbentuk adalah informal, sedangkan basis dari jaringan 
sosial yang terbangun antar individu adalah kekeluargaan. Basis kekeluargaan ini terbangun karena sebagian besar warga memiliki hubungan keluarga.

Tingkat jaringan terhadap lembaga non formal tergolong tinggi, responden menyatakan bahwa peran lembaga non formal seperti LSM INTAN dan lembaga adat sangat membantu masyarakat dalam kegiatan pemanfaatan buah tengkawang. Jaringan baik formal maupun informal sebagai pola pertukaran dan interaksi

Tabel 7. Tingkat modal sosial masyarakat Dusun Melayang dalam pemanfaatan buah tengkawang di hutan Adat Pikul (Table 7. The level of social capital of the people of Dusun Melayang in utilizing tengkawang fruit in the Pikul Adat forest)

\begin{tabular}{lll}
\hline No $\quad$ Unsur modal sosial & Nilai total & Tingkat \\
\hline \multicolumn{2}{l}{ Modal sosial kognitif } & \\
1. Kepercayaan & 480 & Tinggi \\
2. Kerjasama & 170 & Tinggi \\
3. Solidaritas & 365 & Tinggi \\
$\quad$ Jumlah & 1.015 & Tinggi \\
Modal sosial struktural & & \\
1. Aturan & 203 & Sedang \\
2. Peran & 282 & Tinggi \\
3. Jaringan & 272 & Sedang \\
$\quad$ Jumlah & 757 & Sedang \\
\hline$\quad$ Modal sosial & 1.772 & Tinggi \\
\hline Sumber: Hasil Analisis dari data primer, 2020 & &
\end{tabular}

Modal sosial kognitif (kepercayaan, kerjasama, dan solidaritas) termasuk kategori "Tinggi". Modal sosial kognitif yang tinggi pada masyarakat yang memanfaatkan buah tengkawang tersebut tentunya berasal dari proses mental yang diperkuat oleh budaya dan ideologi, norma-norma, nilai-nilai, sikap dan keyakinan seperti ketulusan, kejujuran, sikap empati, belas kasihan, kepedulian, tolong-menolong, tanpa pamrih dan kesetiakawanan sehingga semua itu mendukung tindakan bersama yang saling menguntungkan dalam pengelolaan dan sosial yang terus berkembang merupakan perwujudan penting dari modal sosial. Uphoff (2000) menjelaskan bahwa, sebagai sebuah bentuk organisasi sosial, jaringan mewakili kategori modal sosial struktural. Jaringan ini dapat berkelanjutan lebih karena harapan akan timbal balik (resiprositas), hal ini menunjukkan bahwa ada dominasi kognitif yang penting dalam jaringan yang didorong oleh proses mental masyarakat. 
berperan lebih besar lagi dalam memfasilitasi terciptanya tindakan kolektif yang saling menguntungkan. Beberapa hal yang dapat dilakukan antara lain: mengkoordinasikan berbagai usaha, menciptakan harapan, membuat kemungkinan berhasil lebih besar, dan menyediakan jaminan tentang bagaimana orang lain akan bertindak dan sebagainya dalam rangka pengelolaan dalam pemanfaatan buah tengkawang yang lebih efektif, efisien dan berkelanjutan. Uphoff (2000) menjelaskan bahwa organisasi formal maupun informal dengan segala aturan, peranan, serta dengan interaksi jaringan formal dan informal serta nilai, norma, dan keyakinan yang tersebar di dalam komunitas yang ada dapat memberikan energi dan memperkuat modal sosial, sekaligus dapat menunjukkan bagaimana seseorang dapat memperoleh hasil dan manfaat darinya.

\section{Performansi (Keadaan) Pemanfaatan} buah tengkawang

Produktivitas

Tingkat Jaringan masyarakat dalam pemanfaatan buah tengkawang di hutan adat Pikul secara ringkas disajikan pada Tabel 8.

Tabel 8. Distribusi responden menurut tingkat produktivitas tengkawang di hutan Adat Pikul (Table 8. Distribution of respondents according to tengkawang productivity levels in the Pikul Adat forest)

\begin{tabular}{|c|c|c|c|c|c|}
\hline No & $\begin{array}{c}\text { Tingkat produktivitas } \\
\text { tengkawang }\end{array}$ & $\begin{array}{l}\text { Skor } \\
\text { nilai }\end{array}$ & $\begin{array}{c}\text { Jumlah } \\
\text { responden }\end{array}$ & $\begin{array}{l}\text { Total nilai } \\
\text { (Skor } \mathrm{x} \text { jlh } \\
\text { resp) }\end{array}$ & $\begin{array}{l}\text { Persentase } \\
(\%)\end{array}$ \\
\hline \multirow[t]{4}{*}{1.} & $<$ Rp. 5.375.553/ pertahun & 1 & 2 & 2 & 6,67 \\
\hline & 5.375.553-29.291.113/pertahun & 2 & 28 & 56 & 93,33 \\
\hline & > 29.291.113/pertahun & 3 & 0 & 0 & 0 \\
\hline & Jumlah & & 30 & 58 & 100,00 \\
\hline
\end{tabular}

Produktivitas tengkawang secara umum termasuk kategori yang sedang, responden menyatakan bahwa rata-rata pendapatan pertahun dari hasil panen buah tengkawang adalah adalah Rp.17.333.333,-/KK/Tahun. Responden kunci menjelaskan bahwa pohon Tengkawang berbunga sekitar bulan Oktober sampai Nopember. Pada bulan Desember, pohon tersebut mulai berbuah, sehingga pada bulan Januari dan maret siap untuk dipanen. Serupa dengan penelitian Supartini dan Fajri (2014) di Dusun Sanke, Kecamatan Nanga Taman, Kabupaten Sekadau, Kalimantan Barat yang menyatakan bahwa masyarakat sekitar hutan secara beramai-ramai memungut buah Tengkawang pada bulan
Desember hingga Februari dan berakhir di bulan Maret. Pemungutan dilakukan dengan mengambil buah yang berjatuhan dan meninggalkan buah yang sudah mulai berkecambah. Saat ini tempat penjualan buah tengkawang sudah ada di Dusun Melayang yaitu "kelompok tani tengkawang layar". Organisasi/ kelompok ini membeli buah tengkawang dengan harga yang lumayan tinggi dengan harga Rp. 3.500/ Kg dibandingkan dengan harga pasar yang hanya Rp. 2.500/Kg. Berbeda dengan hasil penelitian yang dilakukan Winarni at al, (2017) harga buah tengkawang adalah Rp.2.750/kg. Perbedaan harga ini menyebabkan masyarakat lebih memilih 
menjual buah tengkawang ke kelompok tani, selain itu jarak tempuh yang dekat serta lebih praktis, karena kelompok tani membeli buah tengkawang yang basah berbeda dengan pembeli lainya yang membeli buah tengkawang dengan kondisi kering.

Buah tengkawang memiliki banyak manfaat baik secara tradisional maupun modern. Secara tradisional, minyak tengkawang digunakan untuk memasak, sebagai penyedap masakan dan ramuan obatobatan. Secara modern atau dalam dunia industri, minyak tengkawang digunakan sebagai bahan pengganti lemak coklat, bahan farmasi dan kosmetik, juga dipakai dalam pembuatan lilin, sabun dan margarin. Minyak tengkawang banyak diperdagangkan dengan nama Green Butter (Winarni et al, 2005). butter) diekspor ke luar negeri dan digunakan sebagai pengganti lemak coklat, bahan farmasi dan bahan kosmetik (Widiyanto dan Siarudin, 2013). Upaya peningkatan produktivitas buah tengkawang dilakukan melalui kegiatan pemeliharaan agar hasil buahnya dapat maksimal. Produktivitas tengkawang juga diproteksi oleh masyarakat melalui cara pemanenan buah dengan pengambil/ pemanenan buah yang jatuh secara alami dari pohonnya. Cara panen dengan tidak memanjat ternyata mampu mempertahankan kualitas dan produktivitas pohonnya.

\section{Keberlanjutan (Sustainabilitas)}

Tingkat keberlanjutan masyarakat dalam pemanfaatan buah tengkawang di hutan adat pikul secara ringkas disajikan pada Tabel 9.

Selain itu, minyak buah tengkawang (green

Tabel 9. Distribusi responden menurut tingkat keberlanjutan tengkawang di hutan Adat Pikul. (Table 9. Distribution of respondents according to tengkawang sustainability level in Pikul Adat forest)

\begin{tabular}{llrlrr}
\hline No & $\begin{array}{l}\text { Tingkat keberlanjutan } \\
\text { tengkawang }\end{array}$ & $\begin{array}{l}\text { Skor } \\
\text { nilai }\end{array}$ & $\begin{array}{l}\text { Jumlah } \\
\text { responden }\end{array}$ & $\begin{array}{l}\text { Total nilai } \\
\text { (Skor x jlh resp) }\end{array}$ & $\begin{array}{l}\text { Persentase } \\
(\%)\end{array}$ \\
\hline 1. & Tidak pernah dilakukan & 1 & 0 & 0 & 0 \\
& Jarang dilakukan & 2 & 5 & 10 & 16,67 \\
& Sering dilakukan & 3 & 25 & 75 & 83,33 \\
& Jumlah & 30 & 85 & 100,00 \\
\hline Sumber: Analisis data, 2020 Jumlah responden 30 orang Ket: kriteria skor nilai: 1(rendah), 2 (sedang) dan 3 (tinggi).
\end{tabular}

Keberadaan pohon tengkawang hidup di dalam hutan adat yang telah lama berfungsi dalam menopang kehidupan masyarakat yang mengelolanya baik secara sosial-ekonomi maupun secara ekologis perlu dipertahankan keberlanjutannya. Wujud dari keinginan masyarakat untuk menjaga keberlanjutan pohon tengkawang dapat terlihat dari sikap dan perbuatan masyarakat yang menyatakan tidak akan merusak hutan adat pikul yang merupakan hasil warisan/ peninggalan dari leluhur mereka. Keinginan untuk menjaga kekestarian hutan adat tersebut demi anak cucu mereka. Upaya yang dilakukan oleh warga untuk mempertahankan dan meningkatkan keberlanjutan pohon tengkawang berupa kegiatan permudaan dan pemeliharaan. Kegiatan pemeliharaan pohon tengkawang dilakukan dengan mengganti pohon yang sudah mati dengan melakukan penanamna kembali. Kegiatan pemeliharaan berupa penyiangan tanaman bawah, pada pohon tengkawang dilakukan sebelum kegiatan panen dengan tujuan untuk memudahkan pemungutan buah tengkawang yang jatuh. Tingkat keberlanjutan tengkawang tergolong tinggi, responden menyatakan kegiatan-kegiatan pemeliharaan 
sering dilakukan untuk mempertahankan keberkanjutan dan kelestarian pohon tengkawang yang ada didalam hutan Adat Pikul. Pohon-pohon yang telah mati di hutan adat diganti dengan bibit tengkawang, hal ini dilakukan secara turun temurun oleh masyarakat Dusun Melayang dengan harapan

Tabel 10. Distribusi responden menurut tingkat keadilan tengkawang (Table 10. Distribution of respondents according to the level of justice in tengkawang)

\begin{tabular}{|c|c|c|c|c|c|}
\hline No & $\begin{array}{l}\text { Pihak yang merasakan } \\
\text { manfaat }\end{array}$ & $\begin{array}{l}\text { Skor } \\
\text { nilai }\end{array}$ & $\begin{array}{c}\text { Jumlah } \\
\text { responden }\end{array}$ & $\begin{array}{c}\text { Total nilai } \\
\text { (Skor } x \text { jlh resp) }\end{array}$ & $\begin{array}{c}\text { Persentase } \\
(\%)\end{array}$ \\
\hline \multirow[t]{4}{*}{1.} & Pemungut tengkawang & 1 & 0 & 0 & 0 \\
\hline & Pemungut dan pembeli & 2 & 7 & 14 & 23,33 \\
\hline & Banyak pihak & 3 & 23 & 69 & 76,67 \\
\hline & Jumlah & & 30 & 83 & 100,00 \\
\hline
\end{tabular}

Tingkat keadilan tengkawang tergolong tinggi responden menyatakan buah tengkawang memberikan manfaat kepada banyak pihak, terutama kepada pemungut buah tengkawang, yang dapat menambah penghasilan keluarga. Sumber daya hutan memiliki beragam fungsi yang memberikan banyak manfaat kepada kehidupan manusia (Monkkonen et.al, 2014). Masyarakat yang tidak memanfaatkan tengkawang juga dapat kelak dapat dimanfaatkan kembali oleh generasi berikutnya.

\section{Keadilan (Ekuitabilitas)}

Tingkat Keadilan masyarakat dalam pemanfaatan buah tengkawang di hutan adat pikul secara ringkas disajikan pada Tabel 10 .

Tabel 11. Tingkatan kategori pemanfaatan tengkawang dan modal social (Table 11. Tengkawang utilization categories and social capital categories)

\begin{tabular}{llll}
\hline No & Unsur performansi & Nilai & Kategori \\
\hline 1. & Produktivitas & 58 & Sedang \\
2. & Keberkanjutan & 85 & Tinggi \\
3. & Keadilan & 83 & Tinggi \\
& Tingkat Performansi & 226 & Tinggi \\
\hline & Tingkat Modal Sosial & 1.772 & Tinggi \\
\hline \multicolumn{2}{l}{ Sumber: Hasil Analisis dari data primer, 2020 } &
\end{tabular}

Tabel 11 menunjukan tingkat modal sosial masyarakat Dusun Melayang yang tinggi dalam pemanfaatan buah tengkawang. Modal sosial yang kuat dapat menjadi pertimbangan pemerintah untuk mendukung program pembangunan (Roslinda et al. 2017). Modal sosial yang merasakan manfaat yang diberikan tengkawang. Hal ini sejalan dengan hasil penelitian Mulyono (2012) menjelaskan tingginya perwujudan solidaritas dan rasa kekeluargaan serta tanggung jawab moril dari komunitas pemilik dukuh kepada warga yang tidak memiliki dukuh. Terciptanya pemerataan distribusi manfaat serta keuntungan hasilnya, distribusi manfaat menyebabkan rasa memiliki dan kebersamaan yang tinggi. 
kemajuan berbagai sektor ekonomi, karena apapun pembangunan ekonomi yang dilakukan, faktor trust, reciprocity, dan nilai-nilai etis merupakan penopang yang akan menentukan perkembangan dan keberlanjutan beragam aktifitas usaha disetiap sektor perekonomian. Penguatan modal sosial masyarakat di kawasan hutan dapat dipandang sebagai investasi atau sumber daya untuk mendapatkan sumber daya baru. Modal Sosial menekankan pada potensi kelompok dan pola-pola hubungan antar individu dalam suatu kelompok dan antar kelompok yang mengandung komponen jaringan sosial, norma, nilai, dan kepercayaan antar sesama yang lahir dari anggota kelompok dan menjadi norma kelompok.

\section{Hubungan Modal Sosial Kognitif dengan pemanfaatan buah tengkawang}

Modal sosial yang tinggi pada masyarakat yang memanfaatakan buah tengkawang dicirikan oleh nilai produktivitas yang tinggi, pemanfaatan sumberdaya yang adil, serta berlangsungnya pengelolaan tengkawang secara berkelanjutan. Pemanfaatan buah tengkawang dipengaruhi oleh modal sosial kognitif korelasinya searah dan kuat, berupa korelasi positif yang menunjukkan semakin tinggi tingkatan unsur-unsur tersebut, semakin tinggi modal sosial yang terbentuk. Unsur-unsur modal sosial kognitif yaitu kepercayaan, kerjasama dan solidaritas semuanya berkorelasi nyata terhadap pemanfaatan buah tengkawang. Masyarakat Dusun Melayang memiliki kepercayaan yang tinggi terhadap sesama dan tokoh adat dalam memanfaatkan tengkawang, sehingga keberkanjutan, produktivitas dari buah tengkawang dapat dirasakan secara adil oleh masyarakat.
Kepercayaan bagi masyarakat pedesaan merupakan komponen utama, tanpa kepercayaan kerjasama dan jaringan tidak akan terbentuk, karena kekuatan kerjasama dan jaringan kerja yang terbentuk berasal dari hubungan saling percaya antar anggota masyarakat (Pranaji 2006).

\section{Hubungan Modal Sosial Struktural dengan pemanfaatan buah tengkawang}

Pemanfaatan buah tengkawang dipengaruhi oleh modal sosial struktural, ketiga unsur modal sosial struktural yang berpengaruh nyata terhadap pemanfaatan buah tengkawang, yaitu: aturan, jaringan dan peranan. Korelasi nyata yang terjadi berupa korelasi positif yang menunjukkan semakin tinggi tingkatan unsur-unsur tersebut, semakin tinggi modal sosial yang terbentuk. Nilai korelasi semakin besar menunjukkan semakin tinggi kontribusi pengaruh unsur-unsur tersebut terhadap modal sosial masyarakat. Unsur modal sosial struktural berupa jaringan dan peran tersebut berkorelasi positif terhadap pemanfaatan buah tengkawang, hal tersebut menunjukkan semakin tinggi tingkat modal sosial struktural berupa jaringan pada masyarakat Dusun Melayang maka semakin baik pula pemanfaatan buah tengkawang di hutan Adat Pikul. Masyarakat membangun dan memelihara hubungan sosial dalam satu komunitas dengan basis ikatan kekeluargaan dan ketetanggaan. Hubungan-hubungan sosial secara umum berlangsung dengan intensitas yang cukup tinggi dan dalam jaringan yang cukup luas. Modal sosial yang tinggi di Dusun Melayang telah memfasilitasi terbentuknya performansi (keadaan) tengkawang yang baik, dicirikan oleh nilai produktivitas yang tinggi, pemanfaatan sumberdaya 
yang adil, serta berlangsungnya pengelolaan tengkawang secara berkelanjutan. Performansi tengkawang yang baik tidak terlepas dari pengaruh modal sosial komunitasnya. Modal sosial dapat menjadi perekat bagi setiap individu dalam bentuk norma-norma, kepercayaan dan jaringan kerja sehingga terjadi kerjasama yang saling menguntungkan untuk mencapai tujuan bersama (Putnam, 1995).

Hasil uji korelasi Peringkat Spearman menunjukkan bahwa modal sosial kognitif dan struktural berpengaruh nyata dan berkorelasi positif terhadap pemanfaatan buah tengkawang, semakin tinggi modal sosial yang dimiliki oleh masyarakat maka semakin tinggi pula harapan untuk terwujudnya performansi tengkawang yang baik karena upaya-upaya pengelolaan tengkawang yang dilakukan masyarakat semakin intensif. Semakin baik performansi tengkawang maka akan semakin menguatkan modal sosial masyarakat karena meningkatnya ekspektasi (harapan) akan aliran manfaat yang dapat mereka rasakan bersama-sama. Dalam pembangunan masyarakat, social capital yang kuat akan meningkatkan kepercayaan dan interaksi yang kuat (Flassy, et al, 2009). Modal sosial memiliki peran yang sangat signifikan terhadap pembangunan, khususnya pembangunan berkelanjutan karena modal sosial merupakan energi kolektif masyarakat guna mengatasi permasalahan bersama dan merupakan sumber motivasi guna mencapai kemajuan ekonomi.

\section{Kesimpulan}

Hasil penelitian terhadap modal sosial dalam pemanfaatan buah tengkawang pada masyarakat Dusun Melayang tergolong “tinggi”. Modal sosial kognitif yang terdiri dari kepercayaan (trust), kerjasama (cooperation), dan solidaritas (solidarity) serta Modal sosial struktural yang terdiri dari aturan (rules), peranan (roles), dan jaringan (networks) keduanya tergolong "tinggi". Modal sosial yang tinggi akan memfasilitasi terbangunnya performansi hutan adat yang lebih baik, dicirikan oleh tingkat produktivitas hutan adat yang tinggi, berlangsungnya pengelolaan hutan adat yang berkelanjutan, manfaat aturan dalam pengelolaan yang adil dan biaya pengelolaan hutan adat yang efisien. Modal sosial yang kuat akan mendorong performansi yang lebih baik.

Hubungan modal sosial terhadap pemanfaatan tengkawang memiliki hubungan yang searah dan kuat, kedua unsur modal sosial Kognitif dan struktural berhubungan sangat nyata terhadap pemanfaatan tengkawang. Hubungan yang dimiliki menunjukkan semakin tinggi tingkatan modal sosial kognitif dan struktural, maka semakin baik pula performansi (keadaan) pemanfaatan buah tengkawang di hutan Adat Pikul.

\section{Saran}

Di dalam upaya mendorong keberlanjutan pengelolaan hutan adat perlu adanya peningkatan peran dan posisi para pihak selain pihak lembaga adat dan LSM, perlu juga melibatkan pihak pemerintah baik pemerintah daerah maupun pemerintah pusat, perlu pula memfasilitasi perluasan jaringan sosial untuk memperoleh infomasi, dan membuat aturan/kebijakan dalam pemasaran hasil produksi kelompok tani tengkawang layar sehingga diharapkan kepercayaan masyarakat terhadap peranan dan jaringan meningkat. Untuk pengurus "kelompok 
tani tengkawang layar" diharapkan dapat segera melegalkan status kelompok taninya dengan membuat akta pendirian kelompok tani tengkawang layar, sehingga pemerintah dapat memberikan batuan dan program-program yang akan mendukung perkembangan masyarakat Dusun Melayang dalam mengelola buah tengkawang secara lestari dan berkelanjutan dalam hutan Adat Pikul.

\section{Ucapan terima kasih}

Penulis mengucapkan terima kasih yang sebesar-besarnya kepada penduduk Dusun Melayang yang telah membantu dalam pelaksanaan penelitian ini

\section{DAFTAR PUSTAKA}

Anen, N. 2012. Modal sosial dalam pengelolaan hutan rakyat lestari di Kabupaten Wonogiri Provinsi Jawa Tengah. Tesis. Sekolah Pascasarjana Institut Pertanian Bogor

Burt, R. S. 1992. Excerpt from the social structure of competition, in structure holes: The social structure of competition. Buku. Harvard. Cambridge, MA and London.

Cahyono, B. 2012. Peran modal sosial dalam peningkatan kesejahteraan masyarakat petani tembakau di Kabupaten Wonosobo. Accounting and Management (CBAM).1(1):131-144.

Coleman JS. 1988. Social capital in the creation of human capital. American Journal of Sociology. Volume 94.

Cox, E. 1995. A Truly Civil Society. Sedney: ABC Books.

Fajri, M. 2008. Pengenalan Umum Dipterocarpaceae, Kelompok Jenis Bernilai Ekonomi Tinggi. Info Teknis Dipterokarpa Vol. 2 No. 1: 9-21. Balai Penelitian Dipterokarpa. Samarinda.

Fajri, M., Fernandes, A. 2015. Pola Pemanenan Buah Tengkawang (Shorea machrophylla) Dan Regenerasi Alaminya Dikebun Masyarakat.
Penelitian Ekosistem Dipterokarpa. Balai Besar Penelitian Dipterokarpa. Samarinda.

Fambayun, R, A. 2014. Budidaya tengkawang untuk kayu pertukangan, bahan makanan dan kerajianan. Penerbit IPP Press

Famiola M, Rudito B,. 2008. Social mapping, Metode Pemetaan Sosial: Teknik Memahami Suatu Masyarakat atau Komuniti. Bandung: Rekayasa Sains

Fauziyah, 2017. Modal Sosial Pada Pengembangan Hutan Kemasyarakatan di Desa Gunung Silanu Kecamatan Bangkala Kabupaten Jenepnto. Skripsi. Program Studi Kehutanan Universitas Hasanuddin Makasar.

Fernandes, A., dan Maharani, R. 2014. Teknologi tepat guna tengkawang. Balai penelitian dipterokarpa. Samarinda.

Fukuyama F. 2007. Trust: kebijakan sosial dan penciptaan kemakmuran. Ruslani, penerjemah. Cetakan kedua. Jakarta: Penerbit Qalam. Terjemahan dari: Trust: The Social Virtues and the Creation of Prosperity.

Fukuyama, F. 1995. Trust: the social virtues and the creation of prosperity. New York: Free Press.

Flassy DJ, Rais S, Supriono A. 2009. Modal sosial: unsur-unsur pembentuk. Jakarta: Bappenas.

Golar, Mahfudz, Malik, A., Muis, H., Khairil, M., Ali, S.S.S., Razman, M.R., Awang, A., 2019. The adaptive-collaborative as a strategy comunications for conflict resolution on the National Park

Hasbullah, J. 2006. Social capital (menuju keunggulan budaya manusia Indonesia). MR-United Press Jakarta. Jakarta.

Hakim, L., Leksono, B., dan Setiadi, D. 2010. Eksplorasi tengkawang (Shorea spp.) di sebaran alam Kalimantan untuk konservasi sumber daya genetik dan populasi pemuliaan. Prosiding Seminar Nasional Mapeki XIII "pengembangan ilmu dan teknologi kayu untuk 
mendukung implementasi program perubahan iklim" p.813-822. Bali.

Jahurul, M.H.A., Zaidul, I.S.M., Norulaini, N.A.N. Sahena, F., Jinap, S., Azmir, J., Sharif, K.M., Omar, A.K.M. 2013. Cocoa butter fats and possibilities of substitution in food products concerning cocoa varieties, alternative source, extraction methods, composition, and characteristics. J Food Eng.

Jones P. 2009. Pengantar teori-teori sosial: dari teori fungsionalisme hingga postmodernisme. Jakarta: Yayasan Obor Indonesi

Mahmud. (2011). Metode penelitian pendidikan. Bandung: Pustaka Setia

Miller DL, Scheffler R, Lam S, Rosenberg R, Rupp A. 2006. Social Capital and Health in Indonesia. World Development Vol. 34, No. 6, pp. 10841098.

Monkkonen, M., Juutinen, A., Mazziotta, A., Miettinen, K., Podkopaev, D., Reunanen, P., Salminen H., Tikkanen, O.P. 2014. Spatially Dynamic Forest Management to Sustain Biodiversity and Economic Returns. J Environ Manag, 134: 80-89.

Mulyono. M.M.B. 2012. Modal sosial dalam pengelolaan kebun hutan (Dukuh) Di Kecamatan Karang Intan Kabupaten Banjar Provinsi Kalimantan Selatan. TESIS. Pascasarjana Institut Pertanian Bogor

Nababan, E.J.K, Qurniati. R, dan Kustanti. A (2016). Modal sosial pada pengelolaan dan pelestarian hutan mangrove di Kecamatan Labuhan Maringgai Kabupaten Lampung Timur. Jurnal sylva Lestari. Vol. 4 No. 2, April 2016 (89-100)

Putnam R.D. 1995. Bowling alone: America's declining social capital. Journal of Democracy. 6(1):65-78 (Online), (https://www.historyofsocialwork.org/1 995 Putnam/1995,\%20Putnam,\%20 bowling\% 20 alone.pdf), diakses 20 September 2019
Pranadji T. 2006. Penguatan modal sosial untuk pemberdayaan masyarakat pedesaan dalam pengelolaan agroekosistem lahan kering. Jurnal Agro Ekonomi 24:178 -206.

Rinawati. R. 2012. Modal sosial masyarakat dalam pembangunan Hutan Rakyat Di Sub Das Cisadane Hulu (kasus di areal model Das Mikro Sub Das Cisadane Hulu). Tesis. Sekolah Pascasarjana Institut Pertanian Bogor.

Romzy. N, Triwahyudianto, dan Wardani.N.R, 2019. MODAL SOSIAL DALAM Pengelolaan Hutan Produksi Pada Lembaga Masyarakat Desa Hutan (LMDH) Desa Pandantoyo Kabupaten Kediri. Jurnal. Vol. 4 No. 1, Maret 2019.

Roslinda E, Ekyastuti W, Kartikawati SM. 2017. Modal sosial pengelolaan hutan rakyat di Desa Nusapati, Kabupaten Mempawah, Kalimantan Barat, Indonesia. Biodiversitas 18 (2): 558564.

Saputro GE. Suharjito D, 2008. Modal Sosial dalam Pengelolaan Sumberdaya Hutan pada Masyarakat Kasepuhan, Banten Kidul. Jurnal Penelitian Sosial dan Ekonomi Kehutanan Vol 5 No 4: 317-335. Bogor: Pusat Penelitian Sosial Ekonomi dan Kebijakan Kehutanan Badan Penelitian dan Pengembangan Kehutanan Kementerian Kehutanan.

Subejo. 2004. Peranan social capital dalam pembangunan ekonomi: suatu pengantar studi social capital di pedesaan Indonesia. Majalah Agro Ekonomi Vol. 11. No.1 Juni 2004.

Suharjito, D., \& Saputro, G. E. 2017. Modal sosial dalam pengelolaan sumberdaya hutan pada masyarakat Kasepuhan, Banten Kidul. Jurnal Penelitian Sosial dan Ekonomi Kehutanan, 5(4): 317-335.

Sumarhani. (2007). Pemanfaatan dan Konservasi Jenis Meranti merah Penghasil Tengkawang. Info Hutan IV (2), 177-185. 
Sunkar. A, Oktadiyani. P dan Muntasib. H (2013). Modal sosial masyarakat di kawasan penyangga Taman Nasional Kutai (TNK) dalam pengembangan ekowisata. Jurnal. Media Konservasi Vol. 18, No. 1 April 2013: 1 -9

Supartini dan Fajri, M. (2014). Produksi buah tengkawang pada beberapa topografi dan dimensi pohon. Jurnal Penelitian Dipterokarpa Vol.8 No.2 Desember 2014

Supranto J. 2000. Statistik, teori dan aplikasi. Tulus $\mathrm{S}$ dan Ali S, Editor. Edisi 6 Cetakan pertama. Jakarta: Erlangga.

Soekanto S. 2009. Sosiologi suatu pengantar. Jakarta: PT. RajaGrafindo Persada.

Thobias, E. 2013. Pengaruh modal sosial terhadap perilaku kewirausahaan (suatu studi pada pelaku usaha mikro kecil menengah di Kecamatan Kabaruan Kabupaten Kepulauan Talaud). Jurnal Acta Diurna.6 (3):125133

Putnam, R.D, 1993. Making democracy work: Civic Traditions in Modern Italy. Princeton University Press. Princeton.

Usman H, Akbar PS. 2008. Metodologi penelitian sosial. Jakarta: Bumi Aksara

Uphoff N. 2000. Understanding social capital: learning from the analysis and experience of participation. In dasguptap and serageldin $i$ (eds). 2000. Social Capital: A Multifaceted
Perspective. Washington DC: The World Bank.

Vipriyanti NU. 2007. Studi sosial ekonomi tentang keterkaitan antara modal sosial dan pembangunan ekonomi wilayah (studi kasus di empat Kabupaten di Provinsi Bali). Disertasi Program Studi Ilmu-Ilmu Perencanaan Pembangunan Wilayah dan Perdesaan Sekolah Pascasarjana Institut Pertanian Bogor. Bogor: Tidak Diterbitkan.

Widiyanto, A dan Siarudin, M. 2013. HHBK minyak lemak, potensi yang perlu dikembangkan. FORPRO, 2(3): 8-15.

Winarni, I., Sumadiwangsa E.S., \& Setyawan D., (2005). Beberapa catataan pohon penghasil biji tengkawang. Info Hasil Hutan 11 (1), 17-25.

Winarni, Budi, Alex, T.Lahjie, A.M dan Ruslim, Y (2017). Analisis produksi dan finansial pengusahaan tengkawang oleh rakyat Di Kalimantan Barat. Jurnal Hutan Tropis Volume 5 No. 3. ISSN 2337-7771

Yuliarmi, N. 2013. Peran modal sosial dalam pemberdayaan industri kerajinan di Provinsi Bali. Jurnal Udayana.(1):715.

Zulfianarisyandra. 2009. Penguatan modal sosial dalam usaha pemberdayaan masyarakat.https://zulfianarisyandra.wo rdpress.com/penguatanmodal-sosialdalam-usaha masyarakat/. pemberdayaan- 